\title{
PENGARUH KONSERVATISME AKUNTANSI, STRUKTUR MODAL, DAN PENGUNGKAPAN CSR TERHADAP EARNING RESPONSE COEFFICIENT
}

\author{
Melvin Ariesta ${ }^{1}$ Heikal Muhammad Zakaria ${ }^{2}$
}

Article history:

Submitted: 4 Juli 2021

Revised: 13 September 2021

Accepted:24 September 2021

\section{Keywords:}

Accounting Conservatism; Capital Structure;

CSR Disclosure;

Earning Response Coefficient.

\section{Kata Kunci:}

Konservatisme Akuntansi;

Struktur Modal;

Pengungkapan CSR;

Earning Response Coefficient.

\section{Koresponding:}

Universitas Singaperbangsa

Karawang, Jawa Barat,

Indonesia

Email:

melvin.ariesta@gmail.com

\section{Abstract}

This study aims to determine the effect of Accounting Conservatism, Capital Structure, and Disclosure of Corporate Social Responsibility on the Earning Response Coefficient of Consumer Goods Sector Companies listed on the Indonesia Stock Exchange for the period 2017-2019. The data used in this study are quantitative data obtained from reports. Company annu al. The sampling technique used purposive sampling. The research population is 41 issuers. The method in this study uses inferential analysis and analyticaltechniques using multiple linear regression analysis to determine the effect between Accounting Conservatism, Capital Structure, and Corporate Social Responsibility Disclosure on Earning Response Coefficient using SPSS 22. The results show that partially accounting conservatism has no effect on the earning response coefficient, but the capital structure and CSR disclosure have a negative effect on the e arning response coefficient.

\begin{tabular}{|c|}
\hline \\
\hline 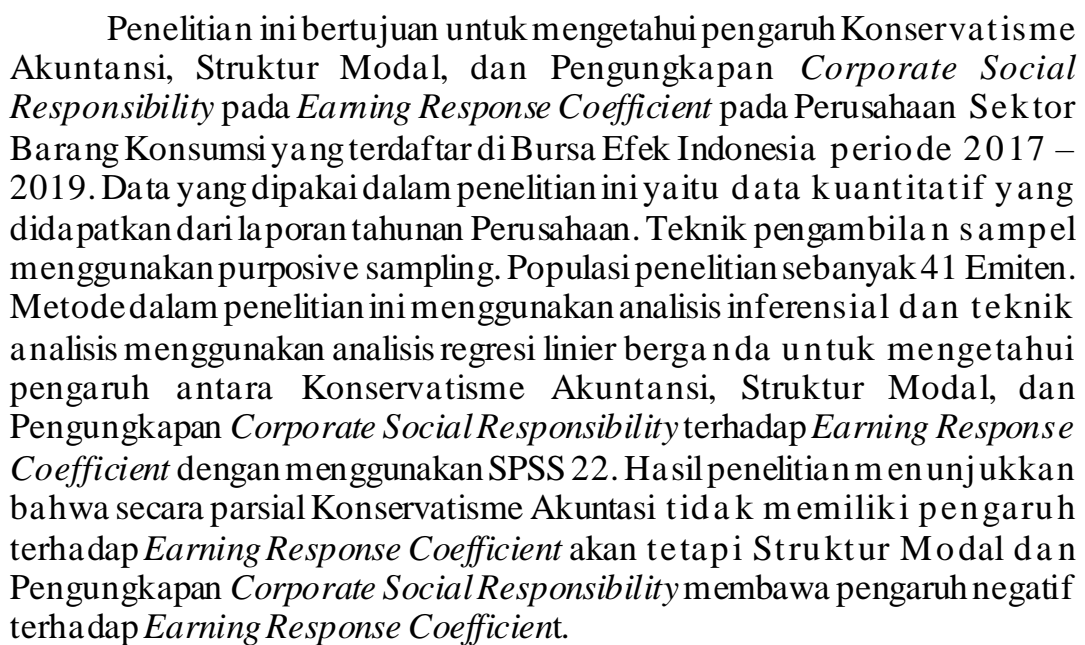 \\
\hline
\end{tabular}




\section{PENDAHULUAN}

Pasar Modal Indonesia atau Indonesia Stock Exchange sudah mengklasifikasikan emiten kedalam sektor dan subsektor untuk mengolongkan jenis emitennya. Pada saat ini telah terdaftar 9 sektor industri diantaranya, pertanian; pertambangan; industri dasar dan kimia; aneka industri; industri barang konsumsi; properti, real estate dan konstruksi bangunan; infrastruktur, utilitas, and transportasi; finansial; perdagangan, jasa, dan investasi. Pada dasarnya setiap sektor memiliki keunggulannya masing masing seperti lazimnya pasar. Pada akhir tahun 2017 sampai akhir 2019 pasar modal meringkas statistik pergerakan indeks 9 sektoral ini dan pada akhir tahun 2018 dan 2019 consumer good industry atau industri barang konsumsi menduduki peringkat masing masing terendah kedua dan pertama dengan $-10,21 \%$ dan $-20,11 \%$. Consumer good industry ini dikenal dengan peringkat kedua terbesar setelah finance industry dengan kapitalisasi pasarnya akan tetapi pergerakan yang dicatat signifikan berbeda.
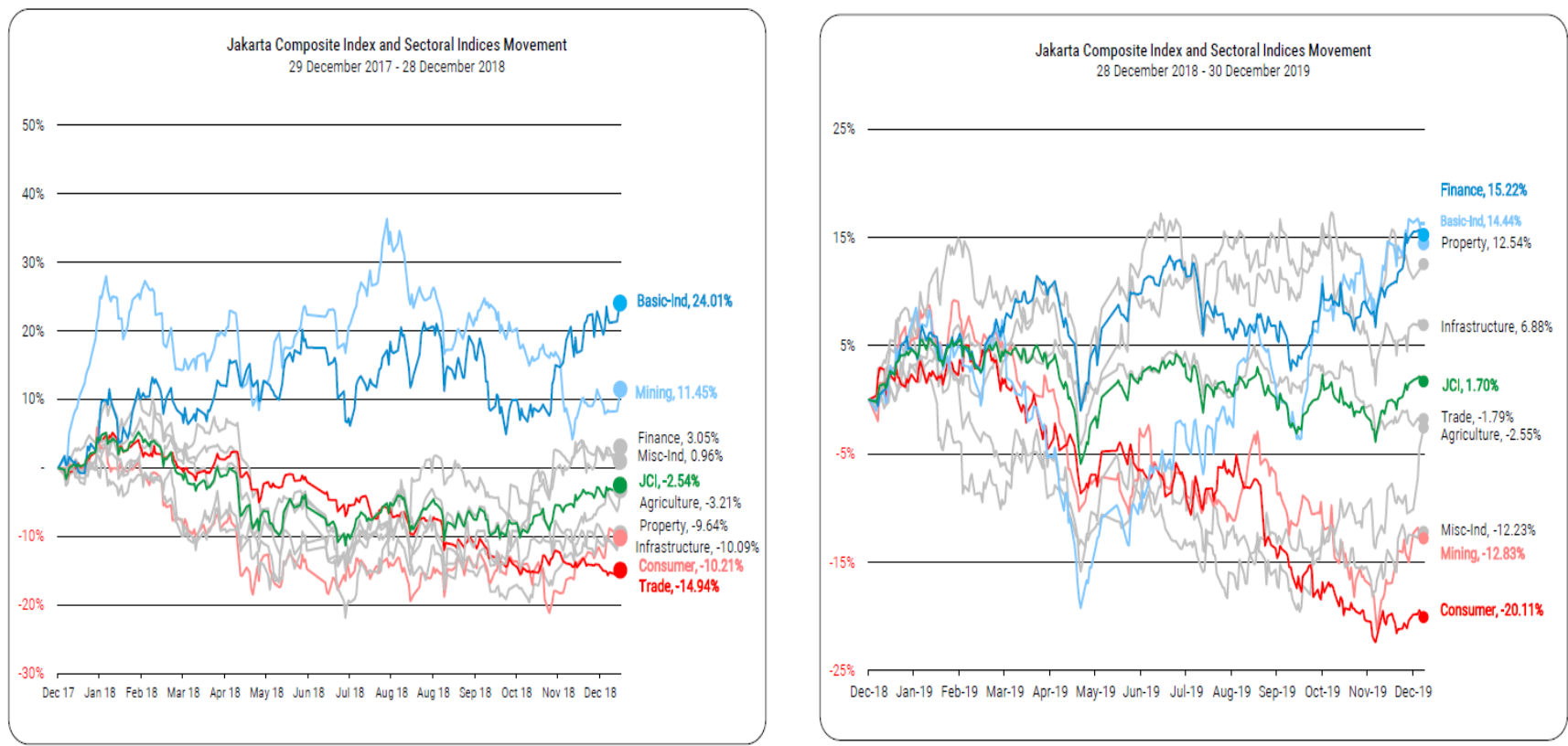

Sumber: Laporan Statistik IDX 2018 dan 2019

\section{Gambar 1. \\ Statistik Pergerakan Indeks Sektoral}

CNBC Indonesia mempublikasikan bahwa kinerja industri barang konsumsi kurang memuaskan, terlihat harga saham - saham dari sektor barang konsumsi berjatuhan pada perdagangan sesi I (CNBC, Kinerja Kurang Memuaskan, Saham Barang Konsumsi Rontok, n.d.). Enam bulan pertama tahun 2019 Unilever mencatat pemasukan sebesar $\mathrm{Rp} 21,46$ triliun atau naik 1,29\% dibandingkan periode yang sama tahun lalu Rp 21.18 triliun. Karenanya penjualan yang tidak terlalu signifikan pertumbuhannya menjadikan laba bersih dinilai pasar kurang memuaskan. Karenanya laba pertumbuhannya tidak diharapkan pasar menjadikan harga saham - saham di sektor barang kon sumsi mengalami penurunan pada perdagangan sesi I. Dalam kasus ini, informasi laba menjadi penyebab dari reaksi nilai perdagangan dalam pasar modal, Diantimala (2008) menyebutkan bahwa informasi utama investor dalam membuat keputusan berinvestasi pada sekuritas yang diterbitkan oleh perusahaan adalah informasi laba.

Pengaruh Konservatisme Akuntansi, Struktur Modal dan Pengungkapan CSRTerhadap Earning Respinse 
Informasi laba masih memiliki kekurangan untuk dapat menjadi pertimbangan karenanya dipengaruhi kemungkinan untuk dimanipulasi oleh manajemen sehingga dibutuhkan informasi lain selain laba untuk memprediksi return saham perusahaan yaitu Earning Response Coefficient (ERC) untuk menilai kualitas dari informasi laba. Kualitas informasi laba ini menjelaskan koefisien atau lambang pengganti untuk mengestimasi hubungan antara return modal dan tingkat tak terduga dalam pengumuman laba perusahaan.

Pada akhir 2018, dikutip pada CNN Indonesia, "Kinerja keuangan lima emiten dengan nilai kapitalisasi terbesar di sektor barang konsumsi rata - rata jauh lebih mengilap dibandingkan tahun lalu" (CNN, Kinerja Emiten Barang Konsumsi Mengilap Di Kuartal III, n.d.). Secara presentase tingkat pertumbuhan pendapatan dan laba bersih mayoritas emiten tersebut menyentuh dua digit pada kuartal III 2018 dibandingkan pada kuarta III 2016 dan 2017 pertumbuhannya hanya satu digit . Fenomena ini tidak dibanjiri respon positif oleh investor, terlihat dari statistik index-nya dari IDX.
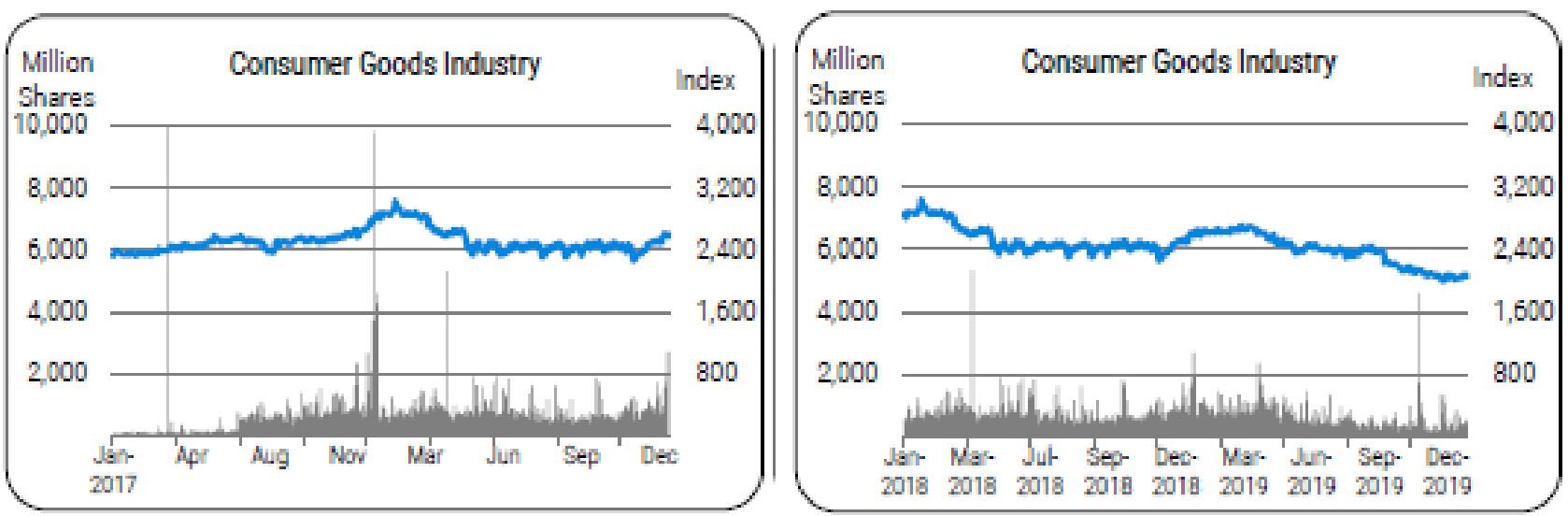

Sumber: Laporan Statistik IDX 2018 dan 2019

Gambar 2.

Statistik Harga Indeks dan Volume Sector Barang Konsumsi Tahun 2017 - 2019

Kuartal III 2018 (Jul - Sep), terlihat indexnya meningkat dan menurun tidak terjadi reaksi yang baik dengan laba yang dilaporkan. Tetapi Irawati (2012) mengutarakan jika laporan laba dalam laporan keuangan dapat mencerminkan kinerja perusahaan yang sesungguhnya dan dengan informasi laba tersebut dapat menunjukan reaksi pasar yang tinggi dari ERC maka dapat diterima bahwa laba tersebut berkualitas. Sehingga banyak komponen yang mempengaruhi nilai dari ERC untuk dapat menjadi pertimbangan investor, seperti konservatisme akuntansi, struktur modal, dan pengungkapan Corporate Social Responsibility (CSR).

Menyajikan informasi yang digunakan publik tentu menuntut tindakan yang teliti dan tingkat kehati - hatian yang tinggi. Demikian penerapan konservatisme pelaporan keuangan banyak dilakukan dalam berbagai lembaga profit. Savitri (2016,), memahami kehati-hatian (prudent) dalam laporan menghasilkan kecenderungan laporan yang pesimisme. Febiani (2012), menyatakan konservatisme ini terjadi karena Standar Akuntansi Keuangan (SAK) memberikan kebebasan memilih metode akuntansi yang digunakan dalam penyusunan laporan keuangan. Prinsip ini menyebabkan laporan keuangan menjadi bias sehingga terjadi kesalahan dalam interpretasi kondisi ekonomi perusahaan (Lasdi, 2009), akan tetapi Wulandari \& Herkulanus (2015) menafsirkan konservatisme akuntansi memiliki peran sebagai pencegahan asimetri informasi dalam teori keagenan dengan membatasi agen melakukan praktik manipulasi laporan dengan menyajikan laba yang tidak overstated. Diantimala (2008) mengartikan konservatisme akuntansi sebagai pilihan manajerial dari metode akuntansi dan estimasi

Pengaruh Konservatisme Akuntansi, Struktur Modal dan Pengungkapan CSRTerhadap Earning Respinse 
dalam Prinsip Akuntansi Berterima Umum (PABU) sehingga mengakibatkan laporan-laporan uderstatement dari nilai laba dan aset. Understatement terjadi karena pengakuan laba yang lambat, pengakuan biaya yang cepat, penilaian aset yang lebih rendah, dan penilaian kewajiban yang lebih tinggi.

Tidak hanya kehati - hatian dalam melaporkan, keputusan investor ditentukan dalam menginterpretasi laporan keuangan, dalam hal ini seluruh aspek didalamnya termasuk struktur modal yang digunakan emiten itu tersendiri. Pemahaman struktur modal adalah perbandingan modal usaha (Ekuitas) dengan modal asing (Liabilitas), Novianti (2015) mengartikan struktur modal sebagai penggunaan sumber daya oleh perusahaan yang memiliki biaya tetap dengan maksud untuk meningkatkan potensial keuntungan. Konflik sering terjadi antara pemegang ekuitas dan pemegang liabilitas dalam penetapan struktur modal optimal suatu perusahaan. Dikembangkan struktur modal ini oleh Romasari (2013) dengan menafsirkan jikalau tingkat pendanaan asset dengan utang maka tingkat leverage juga tinggi dan menjadikan kondisi laba perusahaan semakin baik, akan tetapi pemegang saham (ekuitas) beranggapan laba yang diperoleh hanya menguntungkan pemegang liabilitas (kreditur) sehingga respon pasar saham kurang merespon laba yang dihasilkan perusahaan.

Perusahaan memahami pentingnya informasi yang harus dilaporkan oleh perusahaan untuk menunjukan keadaan sesungguhnya dalam perusahaan, sehingga menyadarkan para penggunanya akan kredibilitas tidak hanya operasional perusahaan tetapi lingkungan perusahaan juga. Sejak diberlakukan UU Nomor 40 tahun 2007 tentang perseroan terbatas menetapkan mengenai Tanggung Jawab Sosial dan Lingkungan atau disebutkan Corporate Social Responsibility (CSR) bersifat sukarela, Pengungkapan CSR pada perusahaan bukan hal-nya untuk mematuhi aturan yang berlaku akan tetapi bermanfaat sebagai keberlangsungan bisnis perusahaan (Awuy, 2016). CSR mempunyai dua karakteristik menurut Hill et al. (2003), pertama, menggambarkan hubungan antara bisnis dan lingkungan luas. Kedua, sama dengan aktivitas perusahaan di area lingkungan sosialnya. Penelitian yang dilakukan oleh Almilia \& Wijayanto (2007) mengambarkan bahwa investor tertarik terhadap informasi sosial yang dilaporkan keuangan. Michael Porter melakukan beberapa kajian tentang "The Competitive Advantage of Corporate Philanthropy" dan menemukan adanya korelasi positif antara profitabilitas dan CSR dengan tujuan finansial dan sosial perusahaan, dengan menunjukan laba tertinggi ditemukan oleh para pionir perusahaan dalam pengungkapan CSR-nya (Untung, 2008).

Penerapan akuntansi konservatisme ini masih menjadi pro dan kontra akan keadaannya dalam memprediksi kualitas laba, seperti pada penelitian Diantimala (2008) menemukan bahwa terdapat pengaruh negatif pada hubungan antara konservatisme akuntansi dengan kualitas laba. Sedangkan Rahayu (2012) dan Setyaningsih (2009) menemukan hubungan positif antara konservatisme akuntansi dengan Koefisien laba. Dan struktur modal perusahaan yang diproksikan dengan besarnya leverage perusahaan yang menyebabkan perusahaan menjadi kurang percaya akan laba yang dilaporkan. Murwaningsari (2008), Irawati (2012) dan Novianti (2015) memiliki bukti empiris yang menunjukan hasil terdapat pengaruh negatif antara leverage terhadap ERC sedangkan Rosmasari (2013) dan Dira \& Astika (2014) menunjukan struktur modal tidak berpengaruh signifikan terhadap ERC. Penelitian mengenai hubungan antara pengungkapan CSR yang diungkapkan dalam laporan tahunan dengan pengaruhnya terhadap kualitas laba, Hidayanti dan Murni (2009) menunjukkan bahwa informasi CSR berpengaruh negatif terhadap relevansi nilai laba. Semakin banyak informasi yang diungkapkan perusahaan mengenai CSR maka relevansi nilai laba semakin menurun. Hal ini mengidentifikasi bahwa investor menggunakan informasi CSR dalam pengambilan keputusan berinvestasi. Sedangkan Restuti \& Nathaniel (2012) dan Silalahi (2014) yang menyatakan bahwa pengungkapan CSR dalam laporan tahunan perusahaan tidak berpengaruh terhadap ERC perusahaan.

Pengaruh Konservatisme Akuntansi, Struktur Modal dan Pengungkapan CSRTerhadap Earning Respinse 
Penelitian ini dilakukan untuk melanjutkan Diantimala (2008) yang mengamati ERC dengan variabel akuntansi konservatisme, ukuran perusahaan dan default risk dan penulis mengganti hubungannya dengan akuntansi konservatisme, struktur modal dan pengungkapan CSR. Penulis menggunakan pengujian dari peneliti - peneliti sebelumnya mengenai pengaruh akuntansi konservatisme, struktur modal dan pengungkapan CSR terhadap ERC sebagai research gap dengan meneliti dari saran sebelumnya. Keanekaragaman penelitian yang meneliti ERC dan dengan hasil yang berbeda pula membuat peneliti tertarik menguji beberapa variabel untuk lebih jauh lagi mengetahui pengaruhnya.

Maka dari itu, dari beberapa hasil yang tidak konsisten tentang faktor - faktor yang berpengaruh terhadap ERC menarik penulis untuk menguji kembali dari penelitian - penelitian sebelumnya. Berdasarkan urainan latar belakang, fenomena, dan penelitian sebelumnya, berakhir dalam maksud penulis untuk melakukan penelitian dengan judul "Pengaruh Akuntansi Konservatisme, Struktur Modal, dan Pengungkapan Corporate Social Responsibility (CSR) terhadap Earning Response Coefficient (ERC)".

Dari paparan sebelumnya bahwa Konservatisme Akuntansi, Struktur Modal, dan Pengungkapan CSR dapat pengaruh dan tidak berpengaruh terhadap ERC. Sehubungan dengan hal itu, maka diajukan hipotesis sebagai berikut: $\mathrm{H}_{1}$ : Konservatisme Akuntansi berpengaruh terhadap ERC pada Perusahaan Sektor Barang Konsumsi periode 2017 - 2019. $\mathrm{H}_{2}$ : Struktur Modal berpengaruh terhadap ERC pada Perusahaan Sektor Barang Konsumsi periode 2017 - 2019. $\mathrm{H}_{3}$ : Pengungkapan CSR berpengaruh terhadap ERC pada Perusahaan Sektor Barang Konsumsi periode 2017 - 2019.

\section{METODE PENELITIAN}

Analisis yang dilakukan dalam penelitian ini menggunakan analisis inferensial atau statistik profitabilitas merupakan analisis yang menggunakan metode statistik untuk menganalisis data sampel dan diberlakukan hasilnya pada populasi (Sugiyono, 2012, p. 148). Terkait Hipotesis yang dikemukakan sebelumnya, peneliti membuat model kerangka pemikiran sebagai berikut:

Sumber: Diolaholeh peneliti, 2021

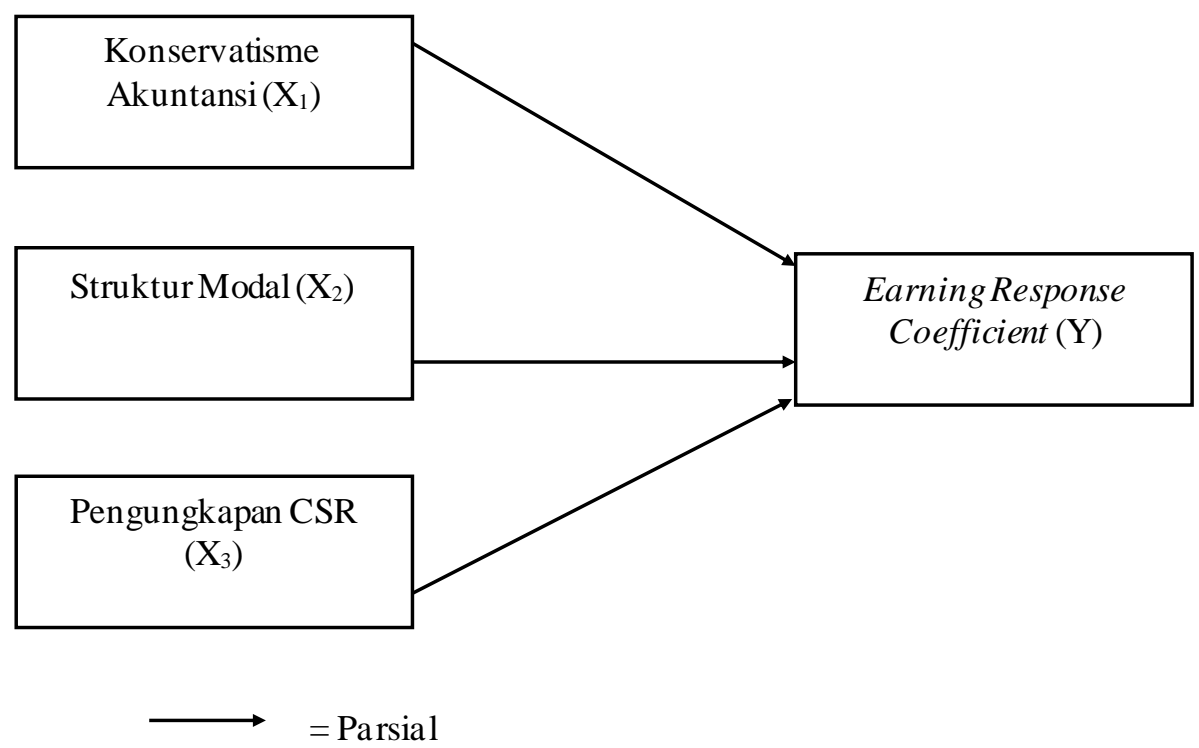

Gambar 3.

Kerangka Pemikiran

Pengaruh Konservatisme Akuntansi, Struktur Modal dan Pengungkapan CSRTerhadap Earning Respinse 
Penelitian ini menggunakan variabel dependen (Y) yaitu ERC, sedangkan variabel independen (X) yang dipakai adalah Konservatisme Akuntansi, Struktur Modal, dan Pengungkapan CSR. Penelitian ini dilakukan pada Perusahaan Sektor Barang Konsumsi yang terdaftar pada Bursa Efek Indonesia dengan tahun pengamatan selama tahun 2017 - 2019. Metode pengumpulan data yaitu dengan mengumpulkan laporan tahunan dan laporan keuangan tahunan yang sudah di publikasikan oleh perusahaan dan informasi lainnya yang diperlukan dalam website Bursa Efek Indonesia yang dijadikan sebagai objek penelitian dan pengumpulan landasan teori yaitu dengan mencari sumber sumber kepustakaan mengenai teori - teori yang relevan dan mendukung berupa jurnal atau buku.

Jenis data yang digunakan adalah data kuantitatif dengan skala rasio dan dengan pertimbangan metode pengumpulan data yang digunakan menjadi data yang diterima adalah data sekunder. Populasi penelitian adalah seluruh perusahaan sektor industri barang konsumsi yang terdaftar pada tahun 2017 sebanyak 46 perusahaan. Teknik pengambilan sampel yang digunakan adalah purposive sampling dengan kriteria sampel termasuk perusahaan industri barang konsumsi yang terdaftar di Bursa Efek Indoensia tahun 2017 dan menerbitkan laporan keuangan tahunan auditan dan laporan tahunan yang dipublikasikan selama tahun 2017, 2018, dan 2019.

Dari kriteria purposive sampling, diperoleh jumlah sampel perusahaan yang digunakan dalam penelitian adalah sebanyak 41 perusahaan. Teknik analisis yang dipakai untuk menguji hipotesis menggunakan analisis regresi linier berganda dengan alat bantu software SPSS 22. Model regresi yang digunakan untuk menguji hipotesis wajib menghindari kemungkinan terjadinya defleksi dari asumsi klasik yang terdiri dari uji normalitas, uji multikolinieritas, uji autokorelasi dan uji heterokedastisitas. Sehingga, jika uji asumsi klasik tidak ada masalah maka penelitian hipotesis dapat dilakukan. Berikut persamaan regresi dalam penelitian ini:

$$
\mathrm{Y}=\alpha+\beta_{1} \mathrm{X}_{1}+\beta_{2} \mathrm{X}_{2}+\beta_{3} \mathrm{X}_{3}+\varepsilon
$$

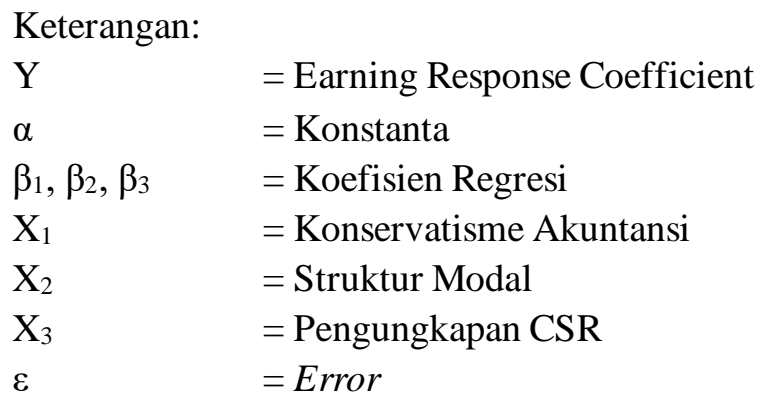

Operasional yang dilakukan dalam mengukur variabel konservatisme akuntansi digunakan akrual non - operasional sebagai indikasi praktik konservatisme akuntansi sejalan dengan penelitian yang dilakukan Untari (2014). Variabel struktur modal digunakan rasio leverage dengan salah satu pengukurannya adalah Debt to Asset (DAR). Variabel pengungkapan CSR diukur menggunakan metode skoring pada indeks GRI (Global Reporting Initiative, 2016) G4 standar khusus pendekatan manajemen dengan memberikan bobot yang berbeda untuk setiap item pengungkapan. Dan untuk variabel dependen, Earning Response Coefficient digunakan koefisien yang didapat dari regresi antara Cummulative Abnormal Return (CAR) dan Unexpected Return (UE) sejalan dengan penelitian yang dilakukan Delvira \& Nelvirita (2013). 


\section{HASIL DAN PEMBAHASAN}

Menganalisis statistik deskriptif untuk menggambarkan data dengan statistik yang mengacu pada nilai mean, standar deviasi, minimum dan maksimum dari variabel penelitian. Digunakan software SPSS 22 sebagai alat bantu dalam pengujian. Peneliti menggunakan data yang sudah diubah dalam bentuk natural (ln) dikarenakan data uji memiliki range yang berbeda jauh antar variabel sehingga diyakini akan menimbulkan pesebaran data uji tidak normal. Berikut adalah hasil data statistik yang diterima dan di analisis oleh peneliti:

Tabel 1.

Statistik Deskriptif

\begin{tabular}{lrrrrrr}
\hline & & \multicolumn{2}{c}{ Ln_X1 } & \multicolumn{2}{c}{ Ln_X2 } & \multicolumn{2}{c}{ Ln_X3 } & \multicolumn{2}{c}{ Ln_Y } \\
\hline $\mathbf{N}$ & Valid & $\mathbf{1 2 3}$ & $\mathbf{1 2 3}$ & $\mathbf{1 2 3}$ & $\mathbf{1 2 3}$ \\
\cline { 2 - 7 } & Missing & $\mathbf{0}$ & $\mathbf{0}$ & $\mathbf{0}$ & $\mathbf{0}$ \\
\hline Mean & 26,3656 & $-1,0832$ & $-2,2479$ & $-5,7626$ \\
\hline \multirow{2}{*}{ Std. Deviation } & 2,19211 & -55018 &, 64579 & 2,12644 \\
\hline Minimum & 21,21 & $-2,66$ & $-3,61$ & $-11,07$ \\
\hline Maximum & 31,29 &,- 26 &,- 87 &, 01 \\
\hline
\end{tabular}

Sumber: Data diproses olehSPSS 22, 2021

Diterima data valid pengamatan sebanyak 123 data. Konservatisme Akuntansi menerima nilai mean sebesar 26.3656 dengan arti lain tingkat kehati-hatian pencatatan rata -rata sampel sejumlah 26.3656. Nilai standar deviasi sebesar 2.19211 dengan arti pesebaran data terhadap rata-rata tingkat kehati-hatian pencatatan sejumlah 2.19211 dan nilai ini dinilai cukup tinggi sehingga data Konservatisme Akuntansi memiliki penyebaran data yang tinggi. Nilai minimum sebesar 21.21 dengan arti tingkat kehati-hatian pencatatan terendah sampel dimiliki dengan nilai 21.21. Nilai maksimum 31.29 dengan arti tingkat kehati-hatian pencatatan tertinggi sampel diperoleh dengan nilai 31.29

Nilai mean yang diterima Struktur Modal sebesar -1.0832 dengan arti rata-rata rasio leverage sampel sejumlah -.0832. Nilai standar deviasi sebesar 0.55018 dengan arti pesebaran data terhadap rata-rata rasio leverage sejumlah 0.55018 dan nilai ini kurang dari satu yang dinilai penyebaran data Struktur Modal normal. nilai minimum sebesar -2.66 dengan arti nilai terendah rasio leverage sejumlah -2.66. nilai maksimum sebesar -0.26 dengan arti nilai tertinggi rasio leverage sejumlah -0.26 .

Nilai mean diterima oleh Pengungkapan CSR sebesar -2.2479 dengan arti rata-rata tingkat pengungkapan sampel sejumlah -2.2479. nilai standar deviasi sebesar 0.64579 dengan arti pesebaran data terhadap rata-rata pengungkapan sejumlah 0.64579 dan penyebaran data Pengungkapan CSR dinilai normal karena standar deviasi tidak lebih dari satu. nilai minimum sebesar -3.61 dengan arti nilai terendah pengungkapan sejumlah -3.61. nilai maksimum sebesar -0.87 dengan arti nilai tertinggi pengungkapan sejumlah -0.87 .

Nilai mean ERC sebesar -5.7626 dengan arti data rata-rata koefisien respon laba sampel sejumlah -5.7626. nilai standar deviasi sebesar 2.12644 dengan arti pesebaran data terhadap rata rata koefisien respon laba sejumlah 2.12644 dan jumlah ini setinngkat dengan tingkat pesebaran data Konservatisme Akuntansi sehingga pesebaran data ERC cukup tinggi. Nilai minimum sebesar -11.07

Pengaruh Konservatisme Akuntansi, Struktur Modal dan Pengungkapan CSRTerhadap Earning Respinse 
dengan arti nilai terendah data koefisien respon laba sejumlah -11.07. nilai maksimum sebesa 0.01 dengan arti nilai tertinggi data koefisien respon laba sejumlah 0.01 .

Tabel 2.

Uji One-Sample Kolmogorov-Smirnov

\begin{tabular}{llr}
\hline & & Unstandardized Residual \\
\hline N & & 123 \\
\cline { 2 - 3 } & Mean &, 0000000 \\
\cline { 2 - 3 } & Std. Deviation & 1,98051192 \\
\cline { 2 - 3 } & Absolute &, 066 \\
\cline { 2 - 3 } & Positive &, 066 \\
\cline { 2 - 3 } & Negative &,- 047 \\
\hline Test Statistic & &, 066 \\
\hline Asymp. Sig. (2-tailed) & &, $200^{\text {c, }}$ \\
\hline SumberemeDifferences & &
\end{tabular}

Sumber: Data diproses oleh SPSS 22,2021.

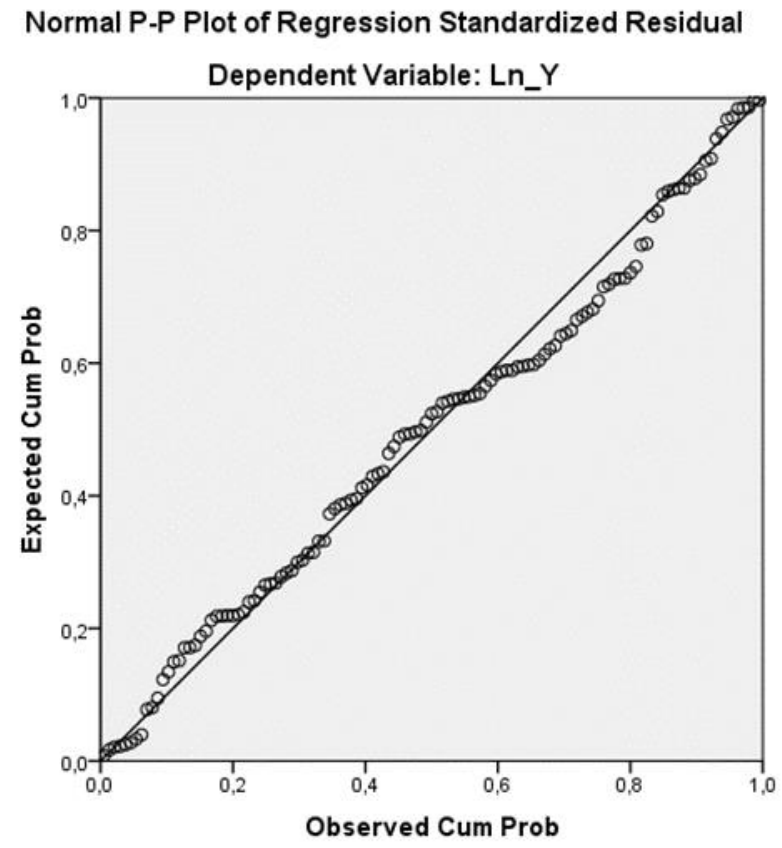

Sumber: Data diproses oleh SPSS 22,2021

Gambar 4.

Grafik Normalitas

Berdasarkan

Tabel

Uji One-Sample Kolmogorov-Smirnov, data pesebaran normal karena nilai sig. (2-tailed) $>0.05$ dan terlihat dari grafik pesebarannya mengikuti garis diagonal. Dengan demikian dapat ditarik kesimpulan dari uji normalitas bahwa data yang digunakan berdistribusi normal.

Uji asumsi klasik berikut adalah uji multikolinearitas, digunakan untuk melihat adanya korelasi antar variabel independen terhadap variabel dependen penelitian dengan melihat angka tolerance dan VIF (variance inflation factor) dengan batasan untuk menunjukan keterjadian multikolinearitas jika nilai tolerance melebihi nilai 0.10 dan nilai VIF kurang dari 10 maka tidak mengalami multikolinearitas. Berikut adalah hasil yang sudah diolah peneliti:

Pengaruh Konservatisme Akuntansi, Struktur Modal dan Pengungkapan CSRTerhadap Earning Respinse 
Tabel 3.

Koefisien Variabel Independen

\begin{tabular}{|c|c|c|c|c|c|c|c|c|}
\hline \multirow[b]{2}{*}{ Model } & & \multicolumn{2}{|c|}{$\begin{array}{c}\text { Unstandardized } \\
\text { Coefficients }\end{array}$} & \multirow{2}{*}{$\begin{array}{c}\text { Standardized } \\
\text { Coefficients } \\
\text { Beta } \\
\end{array}$} & \multirow[b]{2}{*}{$\mathbf{t}$} & \multirow[b]{2}{*}{ Sig. } & \multicolumn{2}{|c|}{$\begin{array}{c}\text { Collinearity } \\
\text { Statistics }\end{array}$} \\
\hline & & B & Std. Error & & & & Tolerance & VIF \\
\hline 1 & (Constant) & $-10,441$ & 2,876 & & $-3,631$ &, 000 & & \\
\hline & $\mathrm{Ln} \_\mathrm{X} 1$ & ,071 & ,093 & ,073 & ,760 & ,449 & ,795 & 1,257 \\
\hline & $\overline{\mathrm{Ln} \_\mathrm{X} 2}$ & $-1,142$ & ,332 &,- 295 & $-3,438$ & , 001 & 987 & 1,013 \\
\hline & Ln_X3 &,- 703 & ,315 &,- 214 & $-2,230$ & ,028 &, 795 & 1,258 \\
\hline
\end{tabular}

Sumber: Data diproses oleh SPSS 22, 2021.

Berdasarkan

Tabel

3.

Koefisien Variabel Independen, terlihat bahwa seluruh variabel independen tidak mengalami multikolinearitas dikarenakan nilai tolerance melebihi nilai 0.10 dan nilai VIF kurang dari 10. Maka dapat disimpulkan bahwa data penelitian tidak terjadi gejala multikolinearitas.

Uji heteroskedastisitas adalah uji asumsi klasik yang bertujuan mengetahui adanya perbedaan varian sisa dalam satu periode pengamatan ke periode pengamatan lainnya dengan melihat pola pada scatterplot. Berikut adalah scatterplot dalam regresi penelitian ini:

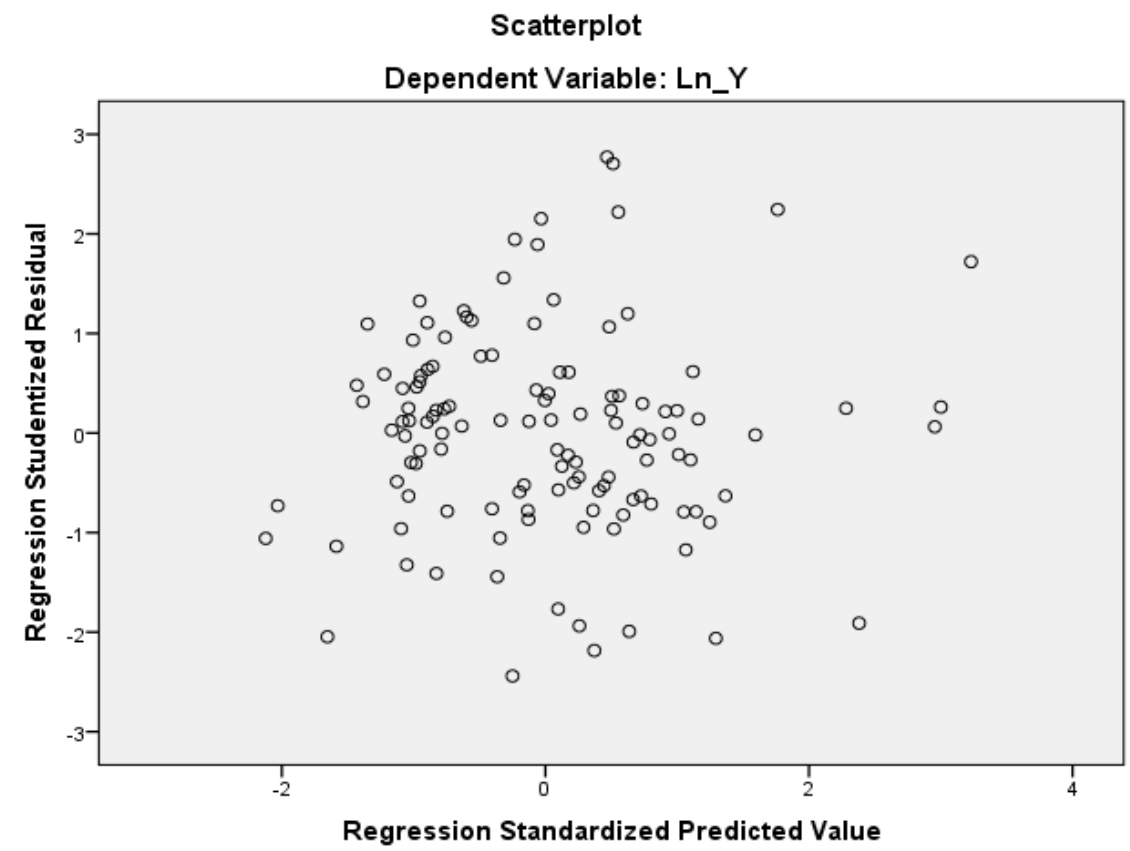

Sumber: Data diproses oleh SPSS 22, 2021

Gambar 5.

Scatterplot Regresi Linier Berganda

Pengaruh Konservatisme Akuntansi, Struktur Modal dan Pengungkapan CSRTerhadap Earning Respinse 
Sacatterplot menunjukan bahwa titik-titik plot menyebar luas diantara angka 0 , sehingga dari penyebaran diterima karena tidak menggambarkan pola tertentu. Oleh karenanya, dapat ditarik kesimpulan bahwa data yang dipergunakan tidak terjadi heteroskedastisitas.

Uji autokorelasi adalah uji asumsi klasik yang bertujuan untuk menentukan apakah adanya korelasi antara variabel yang membinggungkan dan variabel sebelumnya dengan menunjukan hasil model Durbin-Watson dengan ketentuan nilai Durbin-Watson diantara -2 dan +2 maka tidak ada korelasi. Berikut adalah hasil uji yang sudah diolah peneliti:

Tabel 4.

Rangkuman Model Regresi Linear Berganda

\begin{tabular}{lrrrrr} 
Model & R & R Square & Adjusted R Square & $\begin{array}{c}\text { Std. Error of the } \\
\text { Estimate }\end{array}$ & Durbin-Watson \\
\hline 1 &, $364^{\mathrm{a}}$ &, 133 &, 111 & 2,00532 & 1,795 \\
\hline
\end{tabular}

Sumber: Data diproses oleh SPSS 22, 2021.

Berdasarkan

Tabel

4.

Rangkuman Model Regresi Linear Berganda, dihasilkan nilai Durbin-Watson sebesar 1.795 dengan arti nilai tersebut diantara -2 dan +2 . Dan peneliti menyimpulkan, bahwa tidak terjadi autokorelasi dalam model regresi penelitian ini.

Uji asumsi klasik (Uji Normalitas, Uji Multikolinearitas, Uji Heteroskedastisitas dan Uji Autokorelasi) diterima dengan hasil data penelitian normal dan selanjutnya dilakukan uji hipotesis dengan menlakukan uji t, uji F, dan uji $\mathrm{R}^{2}$. Sebelum melakukan pengujian, peneliti memperoleh hasil persamaan regresi yang dihasilkan dengan merujuk Tabel 3. Koefisien Variabel Independen adalah sebagai berikut:

$Y=-10.441+0.071 X_{1}-1.142 X_{2}-0.703 X_{3}$

Berdasarkan persamaan regresi ini, didapat angka konstanta sebesar -10.441 dengan arti lain jika tidak ada perubahan variabel independen, maka konservatisme akuntansi $\left(\mathrm{X}_{1}\right)$, Struktur Modal $\left(\mathrm{X}_{2}\right)$, dan pengungkapan CSR $\left(\mathrm{X}_{3}\right)$ terhadap Variabel Independen ERC (Y) nilai tetap senilai 10,441. Koefisien regresi untuk variabel X1 memiliki nilai positif, yang berarti bahwa ada hubungan yang searah antara $\mathrm{X}_{1}$ dan $\mathrm{Y}$ sebesar 0.071 , sehingga ketika $\mathrm{X}_{1}$ meningkat, menyebabkan $\mathrm{Y}$ meningkat juga dan berlaku sebaliknya. Koefisien regresi untuk variabel $\mathrm{X}_{2}$ memiliki nilai negatif, yang berarti bahwa ada hubungan yang tidak searah antara $\mathrm{X}_{2}$ dan $\mathrm{Y}$ sebesar -1.142, sehingga ketika $\mathrm{X}_{2}$ meningkat, menyebabkan $Y$ menurun dan berlaku sebaliknya. Koefisien regresi untuk variabel $\mathrm{X}_{3}$ memiliki nilai negatif, yang berarti bahwa ada hubungan yang tidak searah antara $X_{3}$ dan $Y$ sebesar -0.703 , sehing a ketika $\mathrm{X}_{3}$ meningkat, menyebabkan $\mathrm{Y}$ menurun dan berlaku sebaliknya.

Pengujian hipotesis dilanjutkan dengan uji $\mathrm{F}$, digunakan untuk menguji bersama-sama variabel independen terhadap variabel independen yang diuji pada tingkat signifikansi tertentu dimana dalam penelitian ini 5\% yang digunakan dengan ketentuan jika $\mathrm{F}$ hitung > nilai $\mathrm{F}$ tabel maka $\mathrm{H}_{0}$ ditolak dan $\mathrm{H}_{\mathrm{a}}$ tidak ditolak, artinya model regresi yang dibuat baik/signifikan maka model bisa digunakan untuk prediksi/peramalan dan berlaku juga sebaliknya. Berikut adalah hasil tabel ANOVA yang dihasilkan dari persamaan regresi linear penelitian:

Pengaruh Konservatisme Akuntansi, Struktur Modal dan Pengungkapan CSRTerhadap Earning Respinse 
Tabel 5.

ANOVA

\begin{tabular}{lllllll}
\hline Model & & Sum of Squares & df & MeanSquare & F & Sig. \\
\hline \multirow{2}{*}{1} & Regression & 73,119 & 3 & 24,373 & 6,061 &, $001^{\mathrm{b}}$ \\
\cline { 2 - 7 } & Residual & 478,536 & 119 & 4,021 & & \\
\cline { 2 - 7 } & Total & 551,656 & 122 & & & \\
\hline
\end{tabular}

Sumber: Data diproses oleh SPSS 22, 2021.

Berdasarkan

Tabel

5.

ANOVA, menghasilkan nilai F hitung sebesar 6.061. mencari F tabelnya dengan menentukan Degree of Freedom (df) pada level signifikansi 5\% atau 0.05, karena variabel independent sebanyak 3 dan

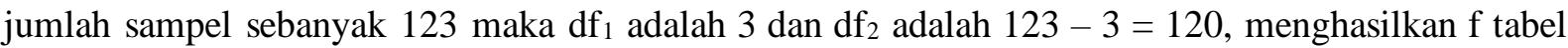
sebesar 2.6802. Dengan membandingkan F hitung dan F tabel maka F hitung $6.061>F$ tabel 2.6802 dan nilai signifikansi lebih kecil dari 0.05 yaitu 0.001, maka dengan artian $\mathrm{H}_{0}$ ditolak dan $\mathrm{H}_{\mathrm{a}}$ tidak ditolak. Di artikan bahwa model regresi baik/signifikan dan bisa digunakan untuk prediksi/peramalan.

Uji hipotesis dilakukan untuk membuktikan hipotesis yang dirumuskan terdapat pengaruh antar variable independen terhadap variable dependen dan Uji-t umumnya digunakan untuk menguji sebagian efek dari setiap variabel independen pada variabel dependen. Berdasarkan dari data sebelumnya, $\mathrm{t}$ tabel yang digunakan adalah data sampel sebanyak $\mathrm{n}=123$ dengan signifikansi level pada 5\% atau level error pada $\alpha=0.05$ dengan 2 -sided tail, didapatkan nilai t tabel $(123 ; 0.05)$ sebesar 1.9794 dan nilai ini sebagai dasar indikator setiap variabel-variabel penelitian dalam pengambilan keputusan hipotesis untuk menerima atau menolak hipotesis awal.

Berdasarkan

Tabel

Koefisien Variabel Independen, nilai signifikansi variabel Konservatisme Akuntansi sebesar 0.449 > 0.05, dengan artian $\mathrm{H}_{0}$ tidak ditolak dan secara parsial variabel $\mathrm{X}_{1}$ tidak mempengaruhi $\mathrm{Y}$. Dan nilai $\mathrm{t}$ hitung $-1.9794<0.760<1.9794$, dengan artian $\mathrm{H}_{0}$ tidak ditolak dan secara parsial variabel $\mathrm{X}_{1}$ tidak mempengaruhi Y. Variabel konservatisme akuntansi tidak mempengaruhi variabel ERC, hasil ini mendukung penelitian yang dilakukan (Untari \& Budiasih, 2014) dengan menemukan kemungkinan bahwa beberapa perusahaan yang diteliti menentukan kebijakan dalam memilih metode akuntansi yang digunakan dan menjadikan konservatisme yang bersifat sementara tidak direaksi oleh pasar dengan artian pelaku pasar telah melakukan antisipasi pada laporan keuangan konservatisme yang tidak persisten. Dan ini juga berhubungan dengan teori sinyal dalam hubungan konservatisme akuntansi dengan earning response coefficient yang menimbulkan sinyal yang lemah dan tidak membuat adanya reaksi terhadap pasar. secara teori agensi, tindakan agen (manajemen) dengan menerapkan sikap kehati-hatian dalam mengakui pendapatan, beban dan utang dengan reaksi principal (investor) tidak mempengaruhi satu dengan lainnya dengan artian lain, agen dan prinsipal memiliki perhatian yang berbeda terhadap laporan yang konservatis.

Berdasarkan

Tabel

Koefisien Variabel Independen, variabel Struktur Modal menerima nilai signifikansi $0.001<0.05$, dengan artian $\mathrm{H} 0$ ditolak dan secara parsial variabel $\mathrm{X}_{2}$ mempengaruhi Y. Nilai t hitung - $3.438<-$

Pengaruh Konservatisme Akuntansi, Struktur Modal dan Pengungkapan CSRTerhadap Earning Respinse 
1.9794, dengan artian $\mathrm{H}_{0}$ ditolak dan secara parsial variabel $\mathrm{X}_{2}$ mempengaruhi $\mathrm{Y}$. Dan nilai koefisien $\mathrm{X}_{2}$ sebesar -1.142 sehingga pengaruh yang ditimbulkan adalah negatif. Hasil ini sejalan dengan (Wahyuni \& Damayanti, 2020) dengan mendapati hasil pengaruh negatif antara struktur modal terhadap ERC diyakini bahwa struktur modal yang tinggi menyebabkan investor kurang percaya terhadap laba yang dipublikasikan oleh perusahaan karena dianggap bahwa perusahaan akan lebih mengutamakan penbayaran hutang terhadap debtholder dari pada pembayaran deviden. Pakar ekonomi meyakini tidak ada satu teori pun yang dapat mengankap segala sesuatu yang mendorong ribuan pilihan struktur permodalan dalam korporasi, akan tetapi dalam kasus ini, permodalan dalam perusahaan sektor barang konsumsi yang terdaftar di Bursa Efek Indonesia periode 2017 - 2019 struktur permodalan dipengaruhi klasik trade-off theory, yang menggambarkan ide tentang seberapa banyak hutang dan modal keuangan perusahaan untuk menikmaati penghematan pajak (tax sheilds) dari tambahan utang sama dengan biaya kesulitan keuangan.

Berdasarkan

Tabel

Koefisien Variabel Independen, nilai signifikansi Pengungkapan CSR sebesar $0.028<0.05$, dengan artian $\mathrm{H}_{0}$ ditolak dan secara parsial variabel $\mathrm{X}_{3}$ mempengaruhi $\mathrm{Y}$. Dan nilai t hitung - $2.230<-1.9794$, dengan artian $\mathrm{H}_{0}$ ditolak dan secara parsial variabel $\mathrm{X}_{3}$ mempengaruhi $\mathrm{Y}$. Dan nilai koefisien $\mathrm{X}_{3}$ sebesar -0.703 sehingga pengaruh yang ditimbulkan adalah negatif. Dengan variabel pengungkapan CSR mempengaruhi variabel ERC secara negatif, bersinambungan dengan penelitian yang dilakukan (Hidayati \& Murni, 2009) dengan menginterpretasikan bahwa informasi CSR mampu mempengaruhi relevansi laba dengan bentuk interaksi negatif, artinya semakin banyak informasi yang diungkapkan perusahaan mengenai CSR mampu menurunkan reaksi investor terhadap kualitas laba yang dilaporkan. Sesuai dengan asumsinya, pengungkapan aktivitas CSR yang berlebihan adalah pengeluaran biaya diluar operasi perusahaan menjadikan laporan laba sulit untuk diprediksi dan berlaku sebaliknya. Merujuk pada teori sinyal, pengungkapan CSR dapat menciptakan informasi asimetris terhadap pelaku pasar dalam menginterpretasikannya. Diyakini terjadi dua asumsi yang berbeda, pertama asumsi investor bahwa laporan CSR hanya sebatas standar hukum yang dilakukan perusahaan untuk bertanggung jawab atas operasi yang dilakukan sehingga ketika perusahaan mengungkapkan banyak aktivitas CSR akan mencerminkan pengeluaran biaya yang berlebih diluar operasi perusahaan dan sebaliknya asumsi kedua, asumsi investor bahwa laporan CSR sebagai pengeluaran yang bermanfaat untuk mendapatkan keuntungan secara tidak langsung atau memperpanjang umur bisnis perusahaan sehingga investor menilai perusahaan yang layak untuk dapat diprediksi laba periode berikutnya. Dan dalam kasus ini, mayoritas investor memiliki asumsi yang pertama dibandingkan asumsi kedua.

Mengetahui seberapa besarnya pengaruh yang dihasilkan variabel independen terhadap variabel dependent maka dilakukan pengujian hipotesis $\mathrm{Uji}^{2} \mathrm{R}^{2}$ atau uji koefisien determinasi. Merujuk pada Tabel

4. Rangkuman Model Regresi Linear Berganda diterima korelasi koefisien sebesar 0.364, dan nilai koefisien derminasi $\left(\mathrm{R}^{2}\right)$ sebesar 0.133 dengan artian pengaruh antara variabel independen terhadap variabel dependen sebesar 13.3 bar\% dan $87.3 \%$ selebihnya dipengaruhi oleh variabel lainnya yang tidak termasuk dalam variabel penelitian ini.

\section{SIMPULAN DAN SARAN}

Berdasarkan analisis dan pengujian yang telah dipaparkan, maka peneliti mengambil simpulan, bahwa Konservatisme Akuntansi secara parsial tidak berpengaruh terhadap Earning

Pengaruh Konservatisme Akuntansi, Struktur Modal dan Pengungkapan CSRTerhadap Earning Respinse 
Response Coefficient (ERC), Struktur Modal secara parsial berpengaruh secara negatif terhadap ERC, dan Pengungkapan Corporate Social Responsibility (CSR) secara parisal berpengaruh secara negatif terhadap ERC. Saran untuk agen (pihak manajemen) diharapkan dapat melakukan manajemen konservatis yang baik dalam melakukan pencatatan, sehingga perusahaan mampu mengurangi kesalahan dalam pengakuan penerimaan atau pengeluaran. Agen juga diharapkan menjaga perbedaan pendanaan pada perusahaan, sehingga dapat menilai reaksi principal (investor, Debitor atau pihak luar sejenis) dengan lebih baik. Penggungkapan sukarela pada laporan diharapkan ditelaah kembali sehingga prinsipal dapat lebih baik menilai perusahaan dengan lebih baik.

Saran untuk penelitian selanjutnya berdasarkan pengalaman penelitian yang telah dilakukan adalah mengembangkan variabel independentnya seperti Pertumbuhan Laba, Ukuran Perusahaan, Likuiditas, Good Corporate Governance, dan Persistensi laba. Dan disarankan untuk mengambil fokus penelitian pada sektor lain atau populasi lainnya dan juga menyarankan untuk menambah periode penelitian agar penelitian semakin baik dan akurat.

\section{REFERENSI}

Awuy, V. P. et al. (2016). Pengaruh Pengungkapan Corporate Social Responsibility (CSR ) Terha dap Earnings Response Coefficient (ERC) ( Suatu StudiEmpiris Pada Perusahaan Pertambangan yang Terdaftar di Bursa Efek Indonesia Pada Tahun 2010-2013 ). Jurnal Akuntansi Dan Keuangan, 18(1), 15-26. https://doi.org/10.9744/jak.18.1.15-26

Delvira, M., \& Nelvirita. (2013). Penga ruh Sistematik, Leverage dan Persistensi Laba terhadap Earnings Response Coeficient(ERC) (Studipada Perusahaan Manufakturyang Go Public di BEI Ta hun 2008 2010). Jurnal WRA, 1(1), 129-154.

Diantimala, Y.(2008). Pengaruh Akuntansi Konservatif, Ukuran Peru sahaan, Dan Def ault Risk Terhadap Koefisien Respon Laba(Erc). JurnalTelaah Dan Riset Akuntansi, 1(1), 102-122.

Dira, P. K., \& Astika, I. B. P. (2014). Pengaruh struktur modal, likuiditas, pertumbuhan laba, dan ukuran perusahaan pada kualitas laba. E-Jurnal Akuntansi Universitas Udayana, 1(7), 64-78.

Febiani, S. (2012). Konservatisme Akuntansi, Corporate Governance, Dan Kualitas Laba (Studi Em piris Pa da Perusahaan Manufaktur Di Bei). Jurnal Ilmiah Mahasiswa Akuntansi, 1(2), 85-91. http://garuda.ristekbrin.go.id/documents/detail/1 13919

GlobalReporting Initiative. (2016). Pedoman Pelaporan Keberla njutan G4 : Prin sip -Prin sip Pelap oran dan Pengungkapan Standar. Global Reporting Initiative, 1-92. www.globalreporting.org

Hidayati, N. N., \& Murni, S. (2009). Pengaruh Pengungka pa n Corporate Social Responsibility Terhadap Earningss Response Coefficient Pada Perusahaan High Profile. Jurnal Bisnis Dan Akuntansi, 11 (1), 1 - 18.

Hill, R.P., Stephens, D., \& Smith, I. (2003). Corporate Social Responsibility: An Examination of Individual Firm Beha vior. Business and Society Review, 108(3), 339-364. https://doi.org/10.111 1/1467-8594.00168

Irawati, D. E. (2012). Pengaruh Struktur Modal, Pertumbuhan Laba, Ukuran Perusahaan Dan Likuiditas Terhadap Kualitas Laba. Accounting Analysis Journal, 1(2), 1-6. https://doi.org/10.15294/aaj.v1i2.572

Kinerja Emiten Barang Konsumsi Mengilap di Kuartal III. (n.d.). Retrieved July 13, 2021, from https://www.cnnindonesia.com/ekonomi/20181102142506-92-343506/kinerja-emiten-barang-k onsumsimengilap-di-kuartal-iii

Kinerja Kurang Memuaskan, Saham Barang Konsumsi Rontok. (n.d.). Retrieved July 13, 2021, from https://www.cnbcindonesia.com/market/20190729132040-17-88257/kinerja-kurang-memuaskan-sahambarang-konsumsi-rontok

Lasdi, L. (2009). Pengujian Determinan Konservatisma Akuntansi. Jurnal Akuntansi Kontemporer, 1(1), 245085. https://doi.org/10.33508/jako.vlil.1035

Murwaningsari, E. (2008). Faktor yang Mempenga ruhi Earning Response Coefficient (ERC). Simposium NasionalAkuntansiXI(1979), 1-27.

Novianti, N. (2015). Pengaruh Struktur Modal, Ukuran Perusahaan, Dan Kebijakan Dividen Terhadap Koefisien Respon Laba. Etikonomi, 13(2), 118-147.https://doi.org/10.15408/etk.v13i2.1882

Rahayu, S. (2012). Pengaruh Konservatisme Laba Terhadap Koefisien Respon Laba Pada Perusahaan Manufaktur Yang Terdaftar Di Bursa Efek Indonesia. http://digilib.unimed.ac.id/id/eprint/12860

Restuti, M. M. D. R., \& Nathaniel, C. (2012). Pengaruh Pengungkapan Corporate Social Responsibility

Pengaruh Konservatisme Akuntansi, Struktur Modal dan Pengungkapan CSRTerhadap Earning Respinse 
Terhadap Earning Response Coefficient. $J d m, 5(2), 171-182$.

Romasari, S. (2013). Pengaruh Persistensi Laba, Struktur Modal, Ukuran Perusahaan dan Alokasi Pa jak Antar Periode Terhadap Kualitas Laba. In Skripsi.

Sa vitri, E. (2016). Konservatisme Akuntansi (Musfialdi(Ed.)). Pustaka Sa hila Yogyakarta.

Setyaningtyas, T. (2009). Pengaruh Konservatisme Laporan Keuangan dan Siklus Hidup Perusahaan Terhadap Koefisien Response Laba (Studi Pada Perusahaan Manufaktur di Bursa Efek Indonesia 2002-2206).

Sila lahi, S. P. (2014). Pengaruh Corporate SocialRespon sibility (CSR) Disclosure, B eta Da n Price To B ook Value (PBV) Terha dap Earnings Response Coefficient (ERC) (StudiEmpiris Pada Perusahaan Manufaktur Yang Terdaftar Di Bursa Efek Indonesia). JurnalEkonomi Universitas Riau, 22(01), 1-14.

Sugiyono. (2012). Metode Penelitian Kuantitatif, Kualitatif, dan R\&D. ALFABETA, CV.

Untari, M. D. A., \& Budiasih, I. G. A. N. (2014). Pengaruh Konservatisme Laba dan Voluntary Disclosure Terhadap Earnings Response Coefficient. E-Jurnal Akuntansi Universitas Udayana, 7(1), 1-18.

Untung, H. B. (2008). Corporate Social Responsibility. Sinar Grafika.

Wahyuni, A., \& Damayanti, C. R. (2020). PENGARUHPERSISTENSILABA, STR UKTUR MODAL DAN CORPORATE SOSIAL RESPONSIBILITY (CSR) TERHADAP EARNING RESPONSE COEFFICIENT (ERC) (Studi Pa da BUMN yang Terdaftar di BEI dan Menggunakan Ped oman Glob bal Reporting Initiative(GRI) G4 Periode 2013-2016). JurnalAdministrasi Bisnis (JAB), 78(1), $38-45$.

Wijayanto, D., \& Almilia, L. S. (2007). Pengaruh_Environmental_Performance_dan_E. https://www.academia.edu/3133724/Pengaruh_Environmental_Performance_dan_Environmental_Disclosu re_terhadap_Economic_Performance?source=swp_share

Wula ndari, I. A. T., \& Herkulanus, B. S. (2015). Good Corporate Governance Dan Pen gu ngkapan Corpora te Social Responsibility Pada Earnings Response Coefficient. E-Jurnal Akuntansi Universitas Udayana, 13(1), 173-190. https://oj s.unud.ac.id/index.php/Akuntansi/article/view/12226 